\title{
Past Human Activity and Geomorphological Change in a Guano-Rich Tropical Cave Mouth: Initial Interpretations of the Late Quaternary Succession in the Great Cave of Niah, Sarawak
}

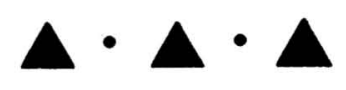

DAVID GILBERTSON, MICHAEL BIRD, CHRISTOPHER HUNT, SUE MCLAREN, RICHARD MANI BANDA, BRIAN PYATT, JAMES ROSE, AND MARK STEPHENS

The Great Cave at Niah is huge and complex. It is developed in the Subis Limestone (Miocene) of Sarawak in northern Borneo (Banda and Heward 2000; Hunt and Dykes 2003). Although Everett et al. (1879-1880) reported the first excavations of the Great Cave, it only became widely known from the excavations in the West Mouth by Tom and Barbara Harrisson in the 1950s and 1960s (Fig. 1; and see this volume: Barker, Fig. 2). These deposits yielded the "Deep Skull"-the remains of an anatomically modern human (Brothwell 1960; illustrated in Hazebroek and Morshidi 2001), associated with radiocarbon dates of ca. 40,000 в.P. from associated charcoal (Harrisson 1958, 1959a, 1965, 1970). Bellwood (1997) suspected a later Pleistocene age, while Gilbertson (2000) questioned both the integrity and interpretation of these ca. 40,000 B.P. dates. Later human use of the cave resulted in hundreds of human skeletons and many thousands of archaeozoological and artifactual items now held in the Niah Cave Archive in the Sarawak Museum, Kuching. However, although important studies of some of these archive materials have since been undertaken (e.g., Cranbrook 2000; Krigbaum 2000, 2003; Rabett 2002), investigations have been hindered by the lack of a clear, published account of the stratigraphy. Zuraina's (1982) excavations clarified many aspects, but they could not resolve the core uncertainties arising from the earlier excavations. She reported the difficulties of relating the in-

David Gilbertson, School of Geography, University of Plymouth, and School of Conservation Sciences, Bournemouth University; Michael Bird, School of Geography and Geosciences, University of St Andrews; Christopher Hunt, Division of Geography, University of Huddersfield; Sue McLaren, Department of Geography, University of Leicester; Richard Mani Banda, Department of Mineral and Geoscience Malaysia Sarawak; Brian Pyatt, Interdisciplinary Biomedical Research Centre, College of Science and Technology, Nottingham Trent University; James Rose and Mark Stephens, Centre for Quaternary Research, Department of Geography, Royal Holloway, University of London. 


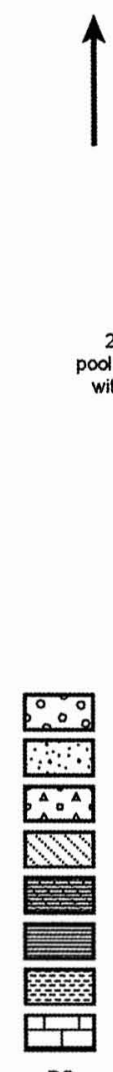

DS

S

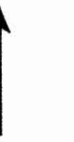

Fig. 1. The location of key sites, features, and units (lithofacies) inside the archaeological reserve at the West Mouth of Niah Great Cave, inside the massif of the Subis Gunong that is made of Subis Limestone (Miocene) in northeast Sarawak (Borneo). DS is the inferred find spot of the Deep Skull within the Hell Trench excavation and may have been (at least partially) overlain by the original western margin of Unit 3 . G (see inset) is the apex of the mound of guano in this cave chamber. Unit 4 is interbedded with Unit 2C and also overlies Units 2, 2C, 3, and 3R. Units C, M, and $\mathrm{G}$ crop out elsewhere in the cave, beyond the boundary fence of the archaeological reserve, and as a result are not shown on this plan. "Tip" is the inferred discarded materials from the excavations of the Harrissons. Cave morphology within this limestone massif is shown in the inset and follows Wilford (1964). The $15 \mathrm{~m}$ above sea level contour is taken from Hazebroek and Morshidi (2001). The same schematic key also applies to Figure 2. 
numerable finds to each other, to their source contexts, and determining the associations between finds, deposits, and the published radiocarbon dates. Anderson (1997) noted these problems for other cave sites in Southeast Asia. Without an understanding of these basic stratigraphic issues, the archaeological and palaeoecological values of the Great Cave and the potential of the Kuching Archive are greatly diminished.

\section{SITE FORMATION IN THE ENTRANCE TO THE GREAT CAVE OF NIAH}

In published accounts of the Great Cave at Niah, the fundamental properties of excavated materials and the deposits or ancient land surfaces with which they were associated are often unclear. Examination of the exposures from the Harrissons' excavations in the initial stages of the present project posed key questions about the sequence and its interpretation, with particular concerns under three headings. First is the "stratigraphic integrity" of finds: the extent to which a sample might be disturbed, compacted, mixed, or otherwise contaminated by older or younger materials; the reliability of inferred relationships between finds and within deposits; and the spatial and stratigraphic relationships between deposits, finds, and features. Second is the chronology of depositional or land-surface environments within the cave; the nature, duration, magnitude, and frequency of natural events and processes; the stability of infill deposits; the extent to which human activity influenced local geomorphological processes; and the relative influence of people or natural taphonomic processes (fall, collapse, water washing, slope mass movement, weathering, desiccation, post-depositional bioturbation or geochemical processes) on the distribution of biological or archaeological remains. Third is the complexities of past geographies within and beyond the cave, and the extent to which events and finds within the cave reflect an environment significantly buffered from possible external larger-scale changes. For these reasons the reinvestigation of the stratigraphy, deposits, ancient land surfaces, and associated finds forms a core component of the present Niah Cave Project. This paper presents a preliminary interpretation of this sequence and its significance.

Despite making several significant text references to distinctive deposits, archaeological phasing, and stratigraphic relationships (though rarely illustrating them in detail), Tom Harrisson $(1958,1959 a, 1959 b, 1970)$ came to believe that, in general, few distinctive deposits or strata could be discerned in the West Mouth of the Great Cave. The origins of the deposits, both "biological" (e.g., bat and bird guano, bones, bioturbation) and "human" (e.g., bones, artifacts, charcoal), were frequently emphasized, as was their taphonomic complexity. He concluded that there was a "lack of the means of petrifaction or mineralization" within the cave sediments: "nothing fossilises, nothing can" (1958:582). Harrisson wrote that at Niah "the normal life of human and most mammal bone is 30,000 years or less; most food shell disintegrates earlier than that" (1970:313). He accepted the integrity and archaeological meaning of the early radiocarbon dates. This led him to establish a quasi-linear age-depth relationship for the correlation and dating of both finds and sediments with the available radiocarbon dates. This approach was later discounted at Niah by Zuraina (1982).

Harrisson's views of site-formation processes, and hence how to understand cave infill sequences in this region, were not unusual for the time. Anderson 
(1997:614) observed that "owing at least in part to the difficulties in unraveling the stratigraphic complexities of cave sites, archaeologists frequently focus their research on chronology and typology." These problems exist in the Great Cave, but the present authors also surmise that Harrisson held views on the operation of geomorphological processes that may have been important in his interpretation: he thought that the cave entrances were "simple" sediment traps that accumulated layers of guano as a result of the "biological drizzle" from bats and swifts in the cave, and (consequently) that the cave entrance sequences were fundamentally different from those then being excavated in temperate latitudes, where sediment textures were thought to reflect past climatic changes (Colcutt 1979).

Harrisson did not publish evidence of significant lateral and temporal variations in sedimentary properties that might have reflected distinctive sediment bodies and former palaeogeographies within the cave entrance. Unpublished observations suggesting this variation, however, exist in the Sarawak Museum's archive in the "site bone books" (Harrisson 1961a), in the stratigraphic drawings of Medway (Barker et al. 2003), in the contemporary accounts of Wilford (1963, 1964), and in the earlier investigations of Everett et al. (1879-1880). Wilford (1964:33) also described diagenetic growths of white secondary minerals in these deposits. These were extensively noted as "white spots" by Harrisson in his field notes and reports (Harrisson 1961a, 1970). Their potential significance, however, is evident in Wilford's illustrations.

During recent decades, ideas about site formation in caves in the humid tropics have developed substantially. Glover (1979), for example, reporting on excavations in Indonesian caves, demonstrated key relationships in cave sedimentation. He emphasized associations between human occupancy and rates of sediment accumulation; variability in rates of sediment accumulation; the importance of a complex of subsidence, fluvial, mass-movement, diagenetic, and karstic processes; variations in drainage direction in cave entrances; and the palaeogeographic significance of spatial distributions of geomorphic features across a cave. He showed how these properties are central to archaeological interpretation. More recently, Esposito et al. (2002) demonstrated the geochemical role of groundwater in diagenesis and metal migration in archaeological materials in Snake Cave, Thailand. Krigbaum (2003) has clarified evidence of differential geochemical change over time to bones and teeth within cave deposits at Niah and elsewhere, previously suspected by Harrisson. More broadly, contemporary archaeological practice gives specific attention to identifying the nature and significance of the many interacting geoarchaeological processes that produced the site and its archaeology. Perhaps the best Asian example of recognition of the fundamental roles of depositional and post-depositional processes in cave sedimentation is the 30-year record of publications from Jelinek et al. (1973) to Weiner et al. (2002) in Israel. Concise modern summaries of such key processes in caves are given by Gillieson (1996), Gunn (2003), and Sasowsky and Mylroie (2003).

\section{LOCAL AND REGIONAL ENVIRONMENTS: PRESENT AND PAST}

The regional climate is described by Tapper (2002). Typical daily air temperatures around $\mathrm{Niah}$ range from $22^{\circ} \mathrm{C}$ before dawn to $32^{\circ} \mathrm{C}$ in the afternoon (Hazebroek and Morshidi 2001). The extent to which microclimates within the Great Cave 
differ from the outside is not known. Hot, humid tropical conditions were reflected, before recent deforestation, by the closed lowland rainforest of great biodiversity in the area (and locally at Niah, by the swamp forests that reach the foot of the massif of the Subis Gunong; Fig. 1). With increasing distance from the equator, as well as at higher elevations, these wet lowland forests are replaced by deciduous forests and savanna woodlands (Ashton 1995; Whiffen 2002).

North of Niah, the oceanic waters of the South China Sea, at present a portion of the Indo-Pacific Warm Pool (Martinez et al. 2002), are part of the warmest seas on Earth, with temperatures nowadays averaging ca. $28^{\circ} \mathrm{C}$ (Yan et al. 1992). This sea is a major driver of the Hadley Circulation, influencing ENSO oscillations associated with the Walker Circulation (Tapper 2002). The high precipitation at Niah (ca. $2000 \mathrm{mma}^{-1}$ ) and inland (ca. $5000 \mathrm{mma}^{-1}$ ) creates substantial runoff that gives relatively low salinity to offshore surface waters. Climate is also modulated by the distinctive seasonal reversal of winds and storms associated with the East Asian and Australian monsoons. El Niño episodes can bring strong and sustained droughts and sometimes fire in the region (Potter 2002). The location of Niah near the modern coast also enhances strong local seasonal variations in climate (Hazebroek and Morshidi 2001).

The present and past characteristics of these climatic relationships (some details of which have been realized only recently) are important to the interpretation of the sequence in the Great Cave. The Harrissons were aware of past eustatic low sea levels and the general characteristics of the exposed continent named "Sundaland" by Molengraaff (1921). Modern palaeogeographical maps (Voris 2000), however, indicate how eustatically driven changes (Lambeck and Chappell 2001) dramatically changed the regional distribution of land and sea, especially when ocean level fell more than 40-50 m. Large continental shelves were progressively exposed, becoming Sunda and Sahul, with land bridges (Kershaw et al. 2001, 2002), rivers and lakes (Voris 2000), and shorter and distinctive coastlines (Dunn and Dunn 1977). The two continents were separated by relatively deep-water north-south channels through the Molluccas and Macassar Strait.

The relationship of the Niah Caves to the coastline at times of low sea was determined by the offshore topography. Only $150 \mathrm{~km}$ north of Niah, the Northwest Sabah Trough-Palawan Trough exceeds $2000 \mathrm{~m}$ (Worldbath Bathymetry 2004). Making no allowance for coastal sedimentation, an eustatic fall of sea level of ca. $120 \mathrm{~m}$ at the LGM (Aharon and Chappell 1986; Yokoyama et al. 2001) would locate the shore ca. $80 \mathrm{~km}$ north of Niah, and extrapolating the constant rate of uplift of ca. $0.19 \mathrm{~m}$ per 1000 years over the last 700,000 years estimated from Mulu (Farrant et al. 1995), it could have been perhaps 5-15 km closer. Using the same assumptions, ocean level at ca. 40,000-45,000 B.P. (the estimated age of the Deep Skull) would have been ca. $40-50 \mathrm{~m}$ below present and the cave would have been ca. $15-30 \mathrm{~km}$ from the shoreline.

Rock or speleothem collapse in these caves (Milne 1966) may have reflected the seismotectonics associated with isostatic loading/unloading, uplift, or crustal flexure, as was recognized for Mulu (Farrant et al. 1995). Regional tectonic uplift is well documented (Metcalf 2002). The Huon Peninsula, New Guinea, near the edge of the Philippine Plate, has experienced uplift rates between 0.5 and $3 \mathrm{~m}$ per thousand years over the last 300,000 years (Ota et al. 1993). However, uncertainties concerning the magnitude of these effects at the local scale prevent 
tectonic and isostatic movements being incorporated into late Quaternary palaeogeographies of the region (e.g., Voris 2000).

Several recent reviews describe the late Quaternary biogeography and climate of the region (Bird et al. 2004; Brandon-Jones 1998; Kershaw et al. 2001, 2002; and references therein). Offshore water temperatures may have been ca. $2-3^{\circ} \mathrm{C}$ lower than today, while air temperatures may have been reduced by $6-7^{\circ} \mathrm{C}$. Cooler temperatures were perhaps associated with a reduction of precipitation by ca. 30-50 percent (Kershaw et al. 2001; van der Kaars et al. 2000). The lowlands such as those around Niah around the LGM (ca. 20,000 years ago) have attracted particular attention. Dry dipterocarp woodland and savanna expanded into regions now occupied by humid lowland rainforest, but lowland rainforest does not appear to have been eliminated. The overall area of lowland rainforest west of Niah may in fact have increased because of the large area exposed by sea level fall (Kershaw et al. 2001).

However, Sun et al. (2000) and Kershaw et al. (2001) have suggested that northeast Borneo, which would include Niah, might have been notably and consistently wetter than much of the rest of Sundaland during the LGM because of the relative proximity of the ocean and the inferred strengthening of the winter monsoon (Gingele et al. 2002). Increased seasonality of climate around Niah during the last glaciation would have resulted. Farther to the northwest, more open vegetation and aridity dominated the extensive coastal plain, perhaps associated with the input of abundant Artemisia pollen and loess from central Asia (Gingele et al. 2002; Sun et al. 2000). Such regional climatological and oceanographic concepts underpin arguments that the "coastal" lands of north and northwest Borneo, including Niah, may have remained sufficiently humid to have been a refugium for lowland rainforest during the late Pleistocene (Brandon-Jones 1998; Gathorne-Hardy et al. 2002; Kershaw et al. 2001). Presbytis and Pongo fossils from Niah, dated to about 40,000 B.P., also imply the local presence of tall evergreen forest (Cranbrook 2000). Likewise, recent pollen diagrams from Lake Sentarum and Setia Alam in west-central and south-central Borneo (Anshari et al. 2001; Kershaw et al. 2001) provide further evidence of tropical rainforest during the LGM.

The proximity of the Niah Caves to the sea may have further bioclimatological significance for palaeoenvironmental reconstruction. Nowadays, periods of moisture stress caused by evapotranspiration are a strong control on lowland rainforest in the region (Baillie 1978; Cranbrook and Edwards 1994; Hazebroek and Morshidi 2001). Past coastal vegetation, with already more strongly seasonal rainfall patterns, would have been rendered even more vulnerable to periods of moisture stress, as a result of frequent and strong coastal breezes. These ideas have considerable importance for predicting the nature and intensity of past geomorphological processes within the Great Cave, permitting the formation of very general hypotheses that can be explored in the cave sequence. Recent understanding of the rapidity of late Pleistocene climate change (Burns et al. 2003; Shackleton et al. 2004) indicates that highly episodic climatic conditions characterized by dry and wet phases and rapid changes of state are likely to have affected geomorphological processes, leading to greater geomorphological instability than occurs today. For instance, more intense winter monsoons would have increased the frequency with which roof and speleothem collapse occurred, and increased the likelihood 
of precipitation reaching the cave floor through roof conduits. Variations in wet evergreen forest would affect cave-dwelling bats and birds and thus the creation of guano. But it must be emphasized that, with the exception of the earlier publications by Cranbrook (2000), there remains a dearth of actual palaeoecological evidence from northern and eastern Borneo.

\section{THE LATE QUATERNARY SEQUENCE OF THE GREAT CAVE OF NIAH: SUMMARY}

Elucidation of the lithostratigraphy and palaeogeography at the site, together with preliminary radiocarbon dating of charcoal from exposures observed between 1999 and 2002 in the West Mouth of the Great Cave, have revealed a relatively simple stratigraphy, though one more complex than that published by the Harrissons (Barker et al. 2000, 2001, 2002a, 2002b, 2003). This new work has involved description, analysis, and interpretation of the geomorphology; description and analysis of the sedimentary and stratigraphic sequence at all the surviving exposures; investigation of depositional and post-depositional sedimentary structures and explicit attention to possible diagenetic changes; recognition of lithofacies architecture in order to reconstruct three-dimensional sediment bodies and relationships to the cave floor topography; the recognition of small-scale and microscale sedimentary and structural features in order to fully understand the depositional and deformational processes (see this volume: Stephens et al.); and awareness of the significance of the contacts between cave entrance deposits and ancient landforms.

The main elements of the sequence within the West Mouth are summarized below and shown in Figures 1-3. Many deposits span considerable periods of time. Examples are the guano of Unit $G$ that collected from ca. 100,000 B.P. to present, and Unit 2C, which accumulated from less than ca. 45,000 B.P. to a few hundred years ago. Some deposits exhibit distinctive interbedding. The lower elements of Unit 2C are interbedded with fluvial and pond deposits of Unit 2, while younger elements are interbedded with the younger basin infill of Unit 4 . The mudflow noted as Unit 3 is similar in thickness to Unit 2, but Unit 3 accumulated in a matter of minutes or hours. The time significance of these lithofacies is therefore quite different in concept from the traditional "layer-cake" model of cave stratigraphies, with one unit stacked on another and becoming progressively younger up the sequence. The lithofacies described here are also different from the units/cultural groups or phases described by Zuraina (1982:70-73, 134-140). The provisional radiocarbon dates of excavated charcoal described here from the West Mouth were determined by Bird using the ABOX-SC technique (Bird et al. 1999). Radiocarbon dates of this antiquity lie beyond the present range of calibration.

Unit $\mathrm{C}$ is a sequence of mottled red and yellow clays, 1-2 $\mathrm{m}$ thick, with secondary carbonates. Their origins are uncertain; the deposit may be a basal part of Unit M. The lithofacies crops out south of the West Mouth "archaeological reserve" (the area protected by a fence today), where a stream leaves the cave entrance. As a result this deposit is not shown in the figures. It appears to be older than any other deposit reported here. 
Unit $\mathrm{M}$ is a diamicton of guano, clay clasts, and limestone boulders up to $5 \mathrm{~m}$ long. This lithofacies is $>10 \mathrm{~m}$ thick and underlies Unit G. Unit M has a lobate planform and reaches the cave mouth, cropping out south of the archaeological reserve, hence it is not shown in Figures 1 and 2. The deposit is suspected to underlie the later deposits. Unit $M$ is interpreted provisionally as a mass-flow deposit.

Unit $\mathrm{G}$ is guano and phosphate rock including secondary gypsum concretions. It crops out south and east of the archaeological reserve (hence it is not shown in Fig. 2) forming a large, elongate, low-angle cone $>9 \mathrm{~m}$ thick (Wilford 1964) with its apex shown as Point $G$ in the inset plan in Figure 1. The unit is derived mainly from bats and swiftlets. Remains of small animals are present. Figure 3 shows at least four distinct facies, with significant nonsequences and angular unconformities evident. Multibanded and multicolored phosphate layers are exposed near the present land surface. These layers are disrupted by faults, deformation, episodes of erosion, and perhaps shrinkage, and by diapiric intrusions of guano (diapiric intrusions are lobate bodies resulting from the upward intrusion of mobile materials - in this case semi-fluid guano - into the overlying materials). Once recognized, such post-depositional features augment rather than confuse stratigraphic interpretation. Guano continues to collect but has been extensively eroded by guano collectors. Near the top of the current guano mound, provisional uncalibrated radiocarbon determinations gave an age of $13,700 \pm 90$ B.P. at $1 \mathrm{~m}$ below the present surface and 29,500 \pm 250 B.P. at $4 \mathrm{~m}$ depth (Hunt and Bird 2002), which led these authors to estimate that the visible guano sequence may date back ca. 100,000 years.

Unit 1 is a pale, light yellowish-brown to yellowish-brown (Munsell 10YR 6/4-6/6) sterile sand without present surface outcrop. The sands contain secondary crystals of selenite up to ca. $2 \mathrm{~cm}$ long. Thickness exceeds $70 \mathrm{~cm}$. The sands occur near the base of the Hell Trench and near the cave wall fissure (Figs. 1 and 2 ). This unit is interpreted as the result of downslope movement of limestone clasts, guano, and sand-sized materials toward the inferred sinkhole beneath the overhang at the northern cave wall (Fig. 1: Point $\mathrm{S}$ within the archaeological reserve). Its western margin in the Hell Trench is erosional and forms a nearvertical boundary with the younger red silts/sands of Unit 2 . This sediment forms the east side of a basin in which Unit 2 was subsequently deposited.

Unit 2C (Yellow Colluvium) has an overall thickness $>2.5 \mathrm{~m}$. Typically it is a sticky, clayey, calcareous (30-79 percent $\left.\mathrm{CaCO}_{3}\right)$, heterogeneous diamicton with $>60$ percent clay and angular small limestone clasts. It is light yellowish-brown to olive yellow (2.5Y $6 / 4$ to $6 / 6)$. It dips into the cave from the cave mouth rampart. Very large clasts from a collapsed column of speleothem occur within this unit immediately west of the modern shelter covering the Hell Trench. In three dimensions, Unit $2 \mathrm{C}$ is an elongate, flat-lying prism, and forms the cave entrance rampart or lip that separates the cave infill deposits from the gorge to the west. Field observation and micromorphological study (this volume: Stephens et al.) indicate that Unit $2 \mathrm{C}$ is primarily a colluvial deposit derived in part from the disintegration of cave mouth speleothem.

The eastern contact of Unit 2C with Unit 2 is an ca. $1 \mathrm{~m}$ wide zone of complex interdigitation between these units (Figs. 2 and 3) and has geomorphological and archaeological significance. Variants in 2C include slope deposits with thin 


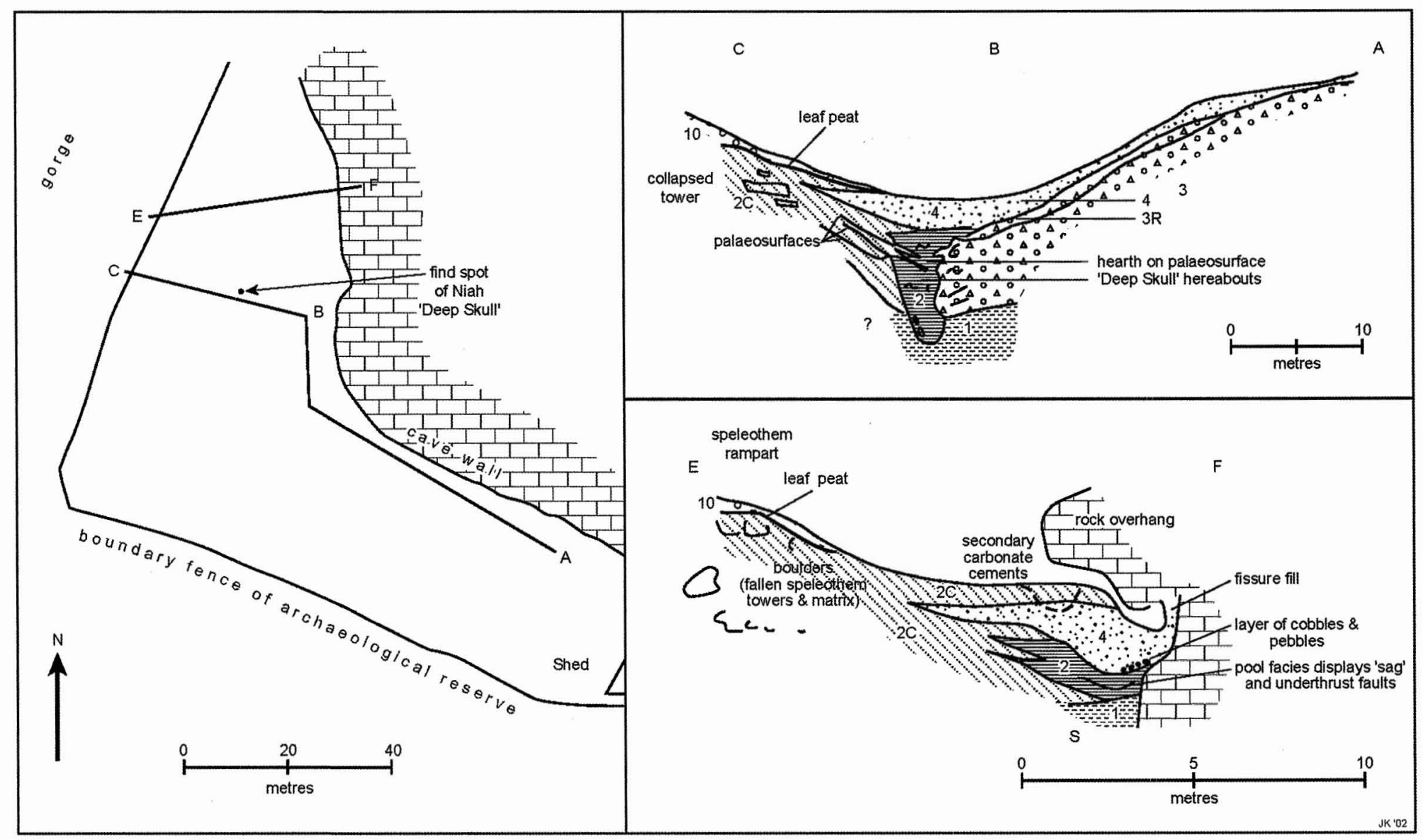

Fig. 2. Schematic representation of the Late Quaternary stratigraphy in the West Mouth of the Great Cave of Niah: along section lines A-B-C and E-F. The schematic stratigraphy in line E-F includes a new interpretation of the unpublished scale stratigraphic drawing made by Lord Medway during excavation in the 1950s that is reported in Barker et al. 2002b (otherwise this figure is a revision of Barker et al. 2001: Fig. 2). See Figure 1 for an explanatory key. Units C, M, and $\mathrm{G}$ do not crop out in the exposures inside the archaeological reserve and as a result are not shown in this diagram. 


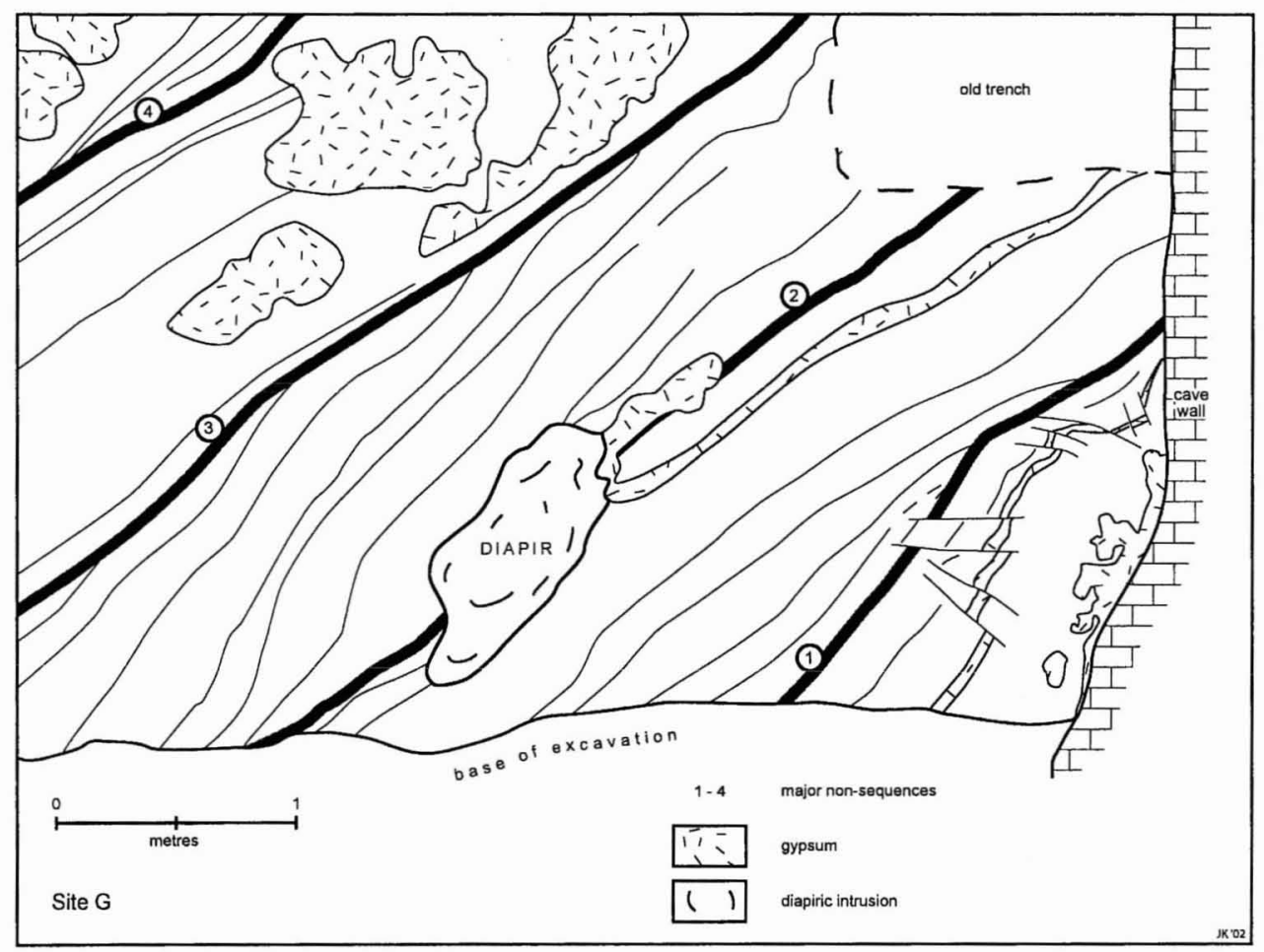

Fig. 3. Field drawing of the sedimentary structures, faults, folds, major nonsequences (1-4), and a diapiric intrusion in the multilayered, multicolored guano sequence of Unit $G$ within the Great Cave of Niah near the apex of the guano mound at point $G$ shown on the inset plan in Figure 1.

(ca. $10 \mathrm{~cm}$ ) layers of wood charcoal, burnt sediment, guano, limestone fragments, biological debris that appears to be reworked organic soils, animal bones and teeth, lithics, and the "palaeosurfaces" shown in section ABC in Fig. 2 (and see this volume: Barker, Fig. 5). There are also lenses of white clayey deposits consisting of 2-16 percent organic matter that, in thin section, were interpreted as wood ash. The composition and stratigraphy of these slope deposits indicate that they variously slid, flowed, washed, or accumulated on a slope extending from the cave lip to the channel episodically occupied by the stream and pool that deposited Unit 2. The morphology of infilled burrows demonstrates a series of temporarily stable palaeosurfaces and further emphasizes the importance of bioturbation in site formation. Charcoal samples from one palaeosurface gave radiocarbon dates of $42,610 \pm 670$ B.P. and $41,800 \pm 620$ B.P. (Barker et al. 2002a). The geometry of this layer extrapolates in Hell Trench to include the inferred find spots of the Deep Skull, and other evidence of human occupation (see below, Unit 2). An unpublished suite of radiocarbon dates by Bird through this stratigraphic level shows a systematic trend from ca. 42,000 B.P. to ca. 38,000 B.P. The very upper part of Unit 2C contains recent materials, including a Chinese medieval sherd that was located beneath leaf peat and midden with diagenetic growths of gypsum (Table 1: Unit 10). 
Table i. The West Mouth of the Great Cave of Niah: Possible Correlations between Lithofacies Provisionally Identified in this Account and Deposits Reported in Previous Studies ${ }^{a}$

\begin{tabular}{|c|c|c|c|c|c|c|}
\hline $\begin{array}{l}\text { EVERETT ET AL. } \\
\text { I } 879-\text { I } 880\end{array}$ & $\begin{array}{l}\text { HARRISSON I958, I970, } \\
\text { AND UNPUBLISHED FIELD } \\
\text { NOTEBOOK MAY I96I }\end{array}$ & WILFORD I964 & ZURAINA I982 & HARRISON I996 & $\begin{array}{l}\text { BARKER ET AL. } \\
2000 \text { UNITS }\end{array}$ & $\begin{array}{l}\text { THIS STUDY: UNIT } \\
\text { (LITHOFACIES) }\end{array}$ \\
\hline \multirow[t]{4}{*}{ Disturbed earth } & & & $\begin{array}{l}\text { Black guano earth? } \\
\text { (p. 42) }\end{array}$ & & Leaf peat & 10 \\
\hline & $\begin{array}{l}\text { Guano and cemetery } \\
\text { deposits; white, } \\
\text { cerise, and } \\
\text { chocolate-colored } \\
\text { archaeological } \\
\text { deposits }\end{array}$ & $\begin{array}{l}\text { Soft-banded, } \\
\text { chocolate and } \\
\text { cream mottled } \\
\text { phosphate; soft } \\
\text { friable cellular } \\
\text { rock of dry red } \\
\text { fragments; buff } \\
\text { clay }\end{array}$ & $\begin{array}{l}\text { Guano and cemetery } \\
\text { deposits }\end{array}$ & & $\begin{array}{l}\text { Guano layers; white, } \\
\text { and brown }\end{array}$ & $5-9$ \\
\hline & $\begin{array}{l}\text { "Frequentation" } \\
\text { zone-earth }\end{array}$ & & $\begin{array}{l}\text { Light-brown soil; } \\
\text { grey brown soil } \\
\text { with white } \\
\text { (powdery) flecks }\end{array}$ & & 4 & 4 \\
\hline & $\begin{array}{l}\text { Sterile; hard; pink and } \\
\text { white bands and } \\
\text { soils; perhaps } \\
\text { volcanic ash? }\end{array}$ & & Pink and white soils & $\begin{array}{l}\text { Airfall of volcanic } \\
\text { ash from Toba } \\
\text { caldera? }\end{array}$ & 3 and $3 R$ & 3 and $3 R$ \\
\hline $\begin{array}{l}\text { Fluviatile and } \\
\text { river mud (?) }\end{array}$ & $\begin{array}{l}\text { Occupation layers of } \\
\text { "habitation" zone; } \\
\text { pink deposit with } \\
\text { clay nodules; dark } \\
\text { pink with clay } \\
\text { nodules; } \\
\text { concentrated bone } \\
\text { deposit; concentrated } \\
\text { ash }\end{array}$ & & $\begin{array}{l}\text { Soft reddish brown } \\
\text { soil; clayey brown } \\
\text { soil; part of hard } \\
\text { dirty brown soil } \\
\text { with white specks } \\
\text { with lumps of } \\
\text { clay and chunks } \\
\text { of limestone } \\
\text { (p. } 45)\end{array}$ & & $2 \mathrm{a}$ and $2 \mathrm{~b}$ & 2 \\
\hline
\end{tabular}




\section{Yellow}

homogeneous

clay: talus of

loam and

clay

\author{
Sticky yellow marl \\ yellowish white, \\ decaying limestone; \\ rockfall
}

Basal clays

Yellowish sterile pink
Hard, clayey, earth

brown in color

(p. 42); moist

clayey soil (p. 42);

part of hard dirty

white brown soil

with white specks

with lumps of

clay and chunks

of limestone? (p

45)

Selenite and

phosphate in

guano cone

Selenite and

phosphate in

guano cone

Clay on cave floor

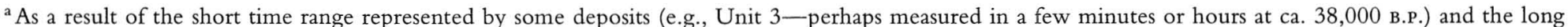
time ranges represented by others (e.g., Unit $\mathrm{G}$ from ca. 100,000 B.P. to present, and Unit 2C, measured from more than ca. 45,000 B.P. to ca. 400 B.P.), the ordering in this table does not imply that any simple chronological sequence exists in the units/lithofacies identified. 
Unit 2 is a complex sequence of characteristically red-brown pond, pool, stream, and mass-movement deposits. At least four episodes of shallow fluvial scour and episodes of complete desiccation can be distinguished. Unit 2 is variable in thickness, reaching an observed maximum of $2.5 \mathrm{~m}$. It occurs in a former topographic depression that existed between the guano mound, the cave mouth rampart of flowstone and limestone blocks, and the rock wall of the cave beneath the overhang (Figs. 1 and 2). When reconstructed, the geometry of Unit 2 has the form of a complex flattened tube with convoluted or eroded margins that opens and flattens northward beneath the overhang. In places, this unit rests against the rock wall of a palaeochannel that trends south-north. It is interbedded along its western margin, from the Hell Trench to beneath the rock overhang, with the lower components of Unit 2C. Its eastern boundary with Unit 3 is often vertical where it has been pushed into and overridden by the impact of that mudflow. In the excavation, Unit 2 appears red, though its field Munsell colors are dark brown/brown/strong brown (7.5 YR 3/4-4/4-4/6). The lower part of Unit 2 contains around 60 percent clay, 20 percent silt, and 20 percent sand, and the upper part contains ca. $\geq 60$ percent silt, 30 percent sand, and little clay. Large clasts (ca. $\leq 10 \mathrm{~cm}^{3}$ ) of reworked bright red clay also occur within it, as often noted by Harrisson (e.g., Harrisson 1961a). Organic matter by loss on ignition at $425^{\circ} \mathrm{C}$ ranges from 3 to 7 percent, and $\mathrm{CaCO}_{3}$ content varies between 1 and 7.5 percent.

Horizontal and ripple bedding indicates low-energy water flow in a channel or at the margin of a pond. Shallow scours indicate at least four episodes of fluvial erosion to ca. $0.3 \mathrm{~m}$ into the sediment surface. Unit 2 also contains distinctive silty clay beds with weak induration and polygonal mud cracks both attributed to desiccation, and bright red rip-up clasts reflecting the reworking of the desiccated muds. There is also clear evidence of small-scale bioturbation and water escape (this volume: Stephens et al.). Localized deformation structures occur at the east margin of the unit because of the lateral impact of Unit 3 (see below). Field inspection indicates that the ephemeral "stream" represented by Unit 2 originated within the cave, with the water entering perhaps through the cave roof, although the exact locations are unclear. The exit for the water is likely to have been through the sinkhole inferred beneath the rock overhang (Fig. 1, Point S), where a pond facies of Unit 2 is interbedded with Units $2 \mathrm{C}$ and 4. A shallow "sag" structure in Units 2 and $2 \mathrm{C}$ at this location provides evidence for subsurface solution. This location also shows post-depositional manganese staining and reverse shear planes. The latter were caused by the lateral impact of the mudflow (Fig. 2, and see below) that is Unit 3 (Fig. 1). A photograph in the Kuching Archive taken during Harrissons' excavations shows this shear zone.

Palaeosurfaces in Unit $2 \mathrm{C}$ interdigitate with Unit 2. Bone, charcoal, and localized evidence of human activity were observed in thin section (this volume: Stephens et al.) and upon excavated palaeosurfaces. One palaeosurface can be extrapolated directly to the inferred find spot of the Deep Skull (see this volume: Barker, Fig. 4). Plant and animal remains and distinctive "concentrated bone" assemblages recorded by Harrisson (1961a) are relatively common in parts of this unit (Table 1). Its palaeotopography indicates that it formed a natural trap in which sediments and human remains have accumulated. Textural and sedimen- 
tary features indicate that the power of the stream was limited and that there is likely to have been little or no damage by turbulence or against the wet-soft channel banks. Some long bones found near the inferred find spot of the Deep Skull are rotten; elsewhere at the interface with Unit $2 \mathrm{C}$, bones have been crushed, perhaps by the impact of the lateral mudflow that came within a meter or so of this location, or by human activity.

Numerous well-preserved organic-walled and siliceous estuarine microfossils were identified in the present investigation through a thickness of sediments ca. $50 \mathrm{~cm}$ above and below the presumed location of the Deep Skull. These are at approximately the same level as markers of the finds of Avicennia (mangrove pollen) left by Jan Müller in the 1950s. Apart from the impact of the mudflow (Unit 3 ) and localized subsidence and manganese staining beneath the rock overhang, there is little or no evidence of modification of Unit 2 after deposition. This field evidence indicates the stratigraphic integrity of each surviving sediment body within Unit 2, including sections close to the inferred find spot of the Deep Skull. The provisional radiocarbon dates from Unit $2 \mathrm{C}$ and at the base of the overlying Unit 3 indicate that Unit 2 was deposited from before ca. 45,000 B.P. and ended at ca. 38,000 B.P. when it was deformed by the impact of the Unit 3 mudflow. The individual scour and fill episodes within Unit 2 may each have been caused by no more than a single high-intensity rainfall event during a few very wet years. The location of this unit behind the cave entrance rampart may have been predominantly dry, as indicated by the desiccated surfaces, with the periods of fluvial activity (erosion and sedimentation) representing very short periods of time.

Unit 3 is a diamicton composed of pink silt-sized material with variably sized white inclusions. The geometry of the unit appears to be tongue-shaped, thinning upslope into the cave. It is interpreted as a mass of sediment derived from Unit $G$ at a higher elevation in the north chamber of the Great Cave (Fig. 1 inset: Point G). The color of the matrix varies from pale brown $(10 \mathrm{YR} 7 / 4-6 / 4)$ to light yellowish-brown (10YR 6/4) to brown (7.5YR 5/4) and light brown (7.5YR 6/3); the inclusions are white. The unit is ca. 1-3 m thick, and contains banding that dips westward toward the cave mouth. The contact with Unit 2 displays interdigitation and deformation with lobes, injection structures, and rip-up clasts of red sand derived from Unit 2 (Fig. 2), as well as small lenses of guano. The texture, banding, and geometry of the unit suggest that it results from a single wet mudflow composed of water-saturated guano. Studies of the contact between Units 3 and 2 indicate that this mudflow plowed into and deformed Units 2 and 2C. It partially overrode and folded the palaeosurface that is traceable to the presumed find spot of the Deep Skull. Field observation, unpublished XRF analyses, and micromorphological study (this volume: Stephens et al.) indicate that what were previously identified by the Harrissons as clasts of roof fall white limestone (the "white" of their "pink and white" deposit) are typically postdepositional growths of gypsum.

Unit $3 \mathrm{R}$ is the upper part of the mudflow lobe that slopes down from the inner part of the cave to the West Mouth. It is a $0.1-1 \mathrm{~m}$ thick silty diamicton with white gravel-size gypsum growths $(<3.5 \mathrm{~cm}$ diameter), with the same Munsell colors as Unit 3. Unlike Unit 3, Unit 3R shows banding throughout, which is 
parallel with the slope of the lobe. $3 \mathrm{R}$ is interpreted as the product of reworking by surface wash and minor mass flow. Locally there are numerous anastamosing, quasi-vertical channels $<1 \mathrm{~cm}$ wide, some of which might be the result of bioturbation. Unit 3R contains charcoal and perhaps some archaeological materials.

Unit 4 consists of a friable brown silty diamicton with occasional cobbles. It occupies an elongate asymmetric basin located mainly beneath the overhang, where small-scale secondary carbonate cementation was noted in the 1950s by Medway (Barker et al. 2003). The deposit is yellowish-brown/dark yellowishbrown/light olive-brown (10YR 5/4-10 YR 4/4-2.5 Y 5/4) in color. Parts are laminated and there is evidence of bioturbation. It is rich in archaeological remains including bones, midden refuse, and mollusks. The carbonate content is 22-52 percent and the organic matter content is $9-11$ percent. The thickness reaches $>4 \mathrm{~m}$ beneath the overhang (Figs. 1 and 2). Significant local subfacies occur: for example, deposits up to $0.6 \mathrm{~m}$ wide accumulated in a gap between the cave wall and Unit 4, possibly as a result of shrinkage or surface wash. The fissure marked in Figure 1 is rich in midden with layers of cobbles, the formation and concentration of which suggest a powerful and directional process that cannot be explained by gravitational forces and is attributed to human activity. Provisional radiocarbon dating indicates that this deposit formed between 19,500 and ca. 8500 years ${ }^{14} \mathrm{C}$ yr uncalibrated (Barker et al. 2002b).

Other deposits younger than Unit 4 occur farther within the cave. Units 5-9 are in situ or reworked layers of guano with complex and rich suites of archaeological remains, especially human remains in excavated graves. They are often notably bioturbated. Occasionally, close to the north wall of the cave, they might be associated with a small ephemeral stream. Unit 10, located on the east flank of the cave mouth rampart, is midden with diagenetic growths of gypsum. Unit 10 has a distinctive $5-10 \mathrm{~cm}$ thick laminated leaf peat at its base, the latter yielding a provisional uncalibrated radiocarbon age of ca. 500 в.P.

\section{CRITICAL PROCESSES OF FORMATION OF THE WEST MOUTH SEDIMENTS} AND GEOMORPHOLOGY

Comparisons between the lithological properties, location, and observed lithostratigraphic positions of the deposits reported here with those recorded previously suggest the correlations set out in Table 1 . The new evidence indicates that the Harrissons were correct in their understanding of the initial biological, airfall, and human origins of much of the materials in the Great Cave of Niah, but evidently that mass movement in the form of mudflow, colluviation, and fluvial and shallow lake activity were also very important geomorphological processes. In addition, peat formation occurred locally, and diagenesis of guano and midden caused alteration of in situ cave sediment.

The guano (Unit G) can be understood as accumulating progressively over time. This is not true of the other units, which appear to be more episodic in character. There is no simple sequence of vertical accretion of airfall biogenic sediment in the cave entrance. The mass-movement deposits of Units C, M, I, and 3 appear to represent single events that may have taken a few days, hours, or even minutes. Much of the (at least) 5000-7000 years represented between the lowest 
and uppermost levels of Unit 2 appear to have been characterized by nondeposition, with episodes of dryness and occasional periods of stream flow and pond development. Local surface wetness within the cave is implied by the reactivation of the surface of the mudflow and the formation of Unit 3R. Units $2 \mathrm{C}$ and $10 \mathrm{dem}-$ onstrate the variety of materials that have accumulated and moved down the cave entrance rampart at different times. Unit $2 \mathrm{C}$ accumulated episodically over the period in which all the other sediments were deposited. In brief, there can be no linear relationship between the thickness of a sediment body in this cave mouth and the length of time it took to accumulate, as rates of accumulation varied considerably according to process and situation.

The recognition of mass movement by parts of the guano is critical for understanding the archaeological record. The textural and morphological properties described for Units 3 and 3R show that they are neither airfall nor reworked volcanic ash as discussed by Harrison (1996; see also Harrisson 1961b, 1961c; Laverty 1983; Wilford 1963), although tephra may exist within them. These are primarily guano-based mudflows, which in the case of $3 \mathrm{R}$ has been further reworked by additional small-scale flows and surface runoff. The significance of the few vertebrate remains from Units 3 and 3R (Cranbrook 2000; 1982) is now clear, given the new understanding of the origins of these deposits. The processes by which guano accumulates as a cone until instability generates flow, deformation, and redeposition are evidently important factors in the development of these tropical cave sediments.

The contacts between several sediment bodies are complex. In some cases beds interdigitate. In other cases the contacts between beds are near vertical, as a result of erosion and subsequent infilling or as a result of lateral impact by a mass flow. These near-vertical contacts were noted by Harrisson (1961a). Other contacts reflect the effects of shrinkage or collapse of sediment bodies; in the Great Cave, this appears to be confined to the interface zone between the sediment bodies and the vertical cave wall.

Together, these relationships reemphasize Anderson's (1997:614-615) observation that cave excavation and research strategies should be appropriate to their tasks. While it is now clear why there are no simple age-depth relationships in this cave mouth sequence, it is equally apparent that a clear, robust, and meaningful litho- and morphostratigraphy exists and can be dated using appropriate techniques. The same integrity is evident in the Harrissons' photographic archive. Perhaps the presence of vertical contacts between sediment bodies, episodes of reworking, or deeper bioturbation may also explain some of the "anomalous" radiocarbon dates obtained from similar tropical cave sequences elsewhere (see Anderson 1997).

This new evidence indicates that Harrisson's (1970) deduction of a progressive loss of biological remains with depth needs to be qualified or disregarded. The good preservation of organic materials reported here in the West Mouth may be because aerobic decay organisms rapidly consumed available oxygen immediately below the sediment/air interface. Additionally, the immense flux of urine from the bats and birds might also have caused the atmosphere near the ground and within the sediments to be saturated with ammonia (Pyatt 2003). On occasion, the toxic combination of anoxia and ammonia may have been enough to limit 
most organic decay. The relationships between burrowing organisms in guano (Gillieson 1966), bioturbation, and soil gases need to be established. Nevertheless, it is possible, given the density of graves and the frequency of recuts in the cemetery, that the Neolithic people who used the cave for burials might have been aware of the preservative properties of the guano soil atmosphere.

Clarifying the magnitude and extent of these geomorphological processes and outcomes has emphasized the stratigraphic importance of Units $2 \mathrm{C}, 2,3$, and 4 for the archaeology of the site. This is particularly the case for Units $2 \mathrm{C}$ and 2, wherein the Deep Skull and associated remains were found. Critically, these units provide evidence of a slowly aggrading land surface that was subjected to episodic flooding, with sequential channeling and deposition, and local subsidence. These surfaces were used by people who had the use of fire. The evidence of their presence and activity is preserved by the impact of the mudflow (Unit 3) that deformed and partially buried the land surface. This mudflow also changed the configuration of this critical part of the cave floor so that it was no longer affected by stream flow. Had this mudflow not taken place, much of the archaeology is likely to have been removed by biological degradation at the land surface or by episodic stream erosion over ca. 38,000 years. Unit 4 is less well understood, but the shallow basin form in which it accumulated must also have been the surface upon which human activity took place. In this case, the human activity contributed specifically to the formation of the diamicton with the addition of clastic detritus, sometimes in the form of limestone or speleothem cobbles, bone and plant debris, as well as the shells of edible mollusks. While both of these units were in the process of formation, the sinkhole appeared to act as the focus for surface runoff and sediment movement.

The results of this investigation suggest a coherent palaeogeography and pattern of past human behavior in the West Mouth of the Great Cave of Niah. People lit fires on the cave rampart and on the dry, sheltered, flat sandy floor behind it. They probably introduced, consumed, and discarded plant and animal parts both in this hollow and on elevated parts of the cave mouth rampart, from where they could see across the gorge from an elevated position (and perhaps also be seen). Collapse of speleothem from the roof of the cave mouth would periodically increase the openness and degree of exposure of this particular part of the cave mouth to the outside world, providing increased access for animals and plant debris, as well as the sun and wind. Human detritus, including plant and animal remains, bones, and artifacts, accumulated on the rampart and would have slipped or tumbled down the slope to also become incorporated in the deposits of Units 2C and 2. The ephemeral "stream" would have transported such materials and incorporated them into, or onto, the stream and shallow pond deposits, but low stream power would have led to little damage.

During the formation of Unit 4, human and natural detritus accumulated on the surface and within a broad, basin-shaped structure on the interior side of the cave rampart, beneath a distinctive but relatively low rock overhang. Natural death, as well as the products of scavenging and decomposition, would have added to the biological materials. The remains of estuarine, freshwater, and terrestrial mollusks and numerous vertebrates, all of which are relatively common, probably found their way into the cave sediments variously through hunting, gathering, and later cultivation, and by natural processes. 


\section{PALAEOENVIRONMENTS AND PALAEOCLIMATE}

The relatively low resolution of parts of the sedimentary sequences means that the relationships between climate and geomorphological processes in the cave remain unclear. In particular, it is not possible to link the mass movement deposits (Units C, M, I, and 3) with specific external climatic forcing (Dykes 2003). All that can be inferred at this stage is that potentially unstable sediments accumulated farther within the cave until excess load created catastrophic failure.

Bearing in mind the problems caused by the low resolution of parts of the evidence, it appears that over the period of 5000-7000 years in which Units 2 and $2 \mathrm{C}$ formed, there was episodic variability in climate. At times, the cave mouth archaeological site experienced wetter conditions characterized by stream flow, shallow ponding, and colluviation. The duration of these events is difficult to estimate, but all the evidence suggests that they were short lived, perhaps only a few very wet seasons, or even less. The argument that dry conditions prevailed most of the time is supported by the results of unpublished pollen and microfossil studies from Unit 2, which indicate that an open, drier, wooded or savannalike landscape surrounded the cave (Hunt and Rushworth in press). The vertebrates recovered by Cranbrook (2000) indicate some tall, wet forest nearby, but there are no clear micropalaeontological indications of the widespread presence of wet lowland tropical rainforest, or of particular stress associated with coastal breezes. All of these lines of evidence emphasize that desiccation cannot be attributed to purely local site factors such as the collapse of the speleothem tower or shifting positions of the stream channel. In addition, the low organic matter content and the significant proportions of carbonate in Unit 2 indicate a moisture deficit, and the presence of quartz silt in the sediment (this volume: Stephens et al.) and steppic pollen in sites in the South China Sea to the north of Niah (Sun et al. 2000) suggest dry monsoonal wind from the Chinese plateau bringing loess and steppic pollen to northern Borneo.

In contrast, Unit 4 has a higher organic content and higher clay and silt contents, but the climatic associations are not fully understood. The present limited evidence points to relatively dry conditions, perhaps with the influx of loess, but with no clear indications of episodic local wetness. This provisional reconstruction may again conform with the predictions of greater aridity and marked airflow from the north (Gingele et al. 2002; Kershaw et al. 2001; Sun et al. 2000). There are no clear indications of either greater local wetness or greater moisture stress associated with the relative proximity of the ocean to Niah.

\section{CONCLUSIONS}

An integrated history of the Niah Great Cave over the last 100,000 years is summarized in Table 2 and set out in more detail below. The first series of events occurred in the outer part of the cave mouth adjacent to the cave-mouth rampart.

In the cave interior area, a guano pile may have been accumulated over ca. 100,000 years.

From before ca. 45,000 B.P. to the present, a complex linear rampart developed episodically along the cave entrance. This was formed of standing and collapsed speleothem towers, clay-rich colluvium derived from weathered speleothem, 
Table 2. A Summary Provisional Event Sequence for the West Mouth of the Great Cave of Niah and its Surrounding Area from Ca. 50,000 to 5000 B.P. ${ }^{a}$

\begin{tabular}{|c|c|}
\hline DATE & EVENTS \\
\hline $\begin{array}{l}\text { Ca. mid } \\
\text { Holocene- } \\
\text { "Neolithic" }\end{array}$ & $\begin{array}{l}\text { Relative hiatus in human activity. Guano accumulation continues in Unit } \\
\mathrm{G} \text { and elsewhere. Seashore of mangroves adjacent to the Great Cave. } \\
\text { Intensive use of West Mouth as burial area. Recycling of guano by } \\
\text { surface wash and flow; pits were dug. Extensive bioturbation of surface } \\
\text { deposits, but not reaching to the older Pleistocene deposits. }\end{array}$ \\
\hline $\begin{array}{l}\text { Ca. } 30,000 \text { B.P. to } \\
\text { ca. early Holocene }\end{array}$ & $\begin{array}{l}\text { Accumulation of anthropogenic deposits with admixtures of natural } \\
\text { materials (perhaps including wind-blown silts) to form Unit } 4 \text {. These } \\
\text { collect in a shallow basin that is a natural sediment trap beneath the rock } \\
\text { overhang in the cave; continued accumulation of both Unit } 2 \mathrm{C} \text { and } \\
\text { guano (Unit } \mathrm{G} \text { ); locally, guano is reworked. }\end{array}$ \\
\hline $\begin{array}{l}\text { Ca. } 40,000 \text { B.P.- } \\
\text { ca. } 38,000 \text { B.P. }\end{array}$ & $\begin{array}{l}\text { "Instantaneous" mudflow of guano (Unit 3) from edge of the guano pile } \\
\text { of Unit G reaches the West Mouth and impacts on Units } 2 \text { and } 2 \mathrm{C} \text {. } \\
\text { Continued accumulation of guano mound (Unit G). }\end{array}$ \\
\hline $\begin{array}{l}\text { More than } 45,000 \\
\text { B.P. }- \text { ca. } 38,000 \\
\text { B.P. }\end{array}$ & $\begin{array}{l}\text { Accumulation of Units } 2 \text { and } 2 \mathrm{C} \text {, which are interbedded along a complex } \\
\text { slope-stream margin and stream-pool depositional environment that } \\
\text { runs parallel to the cave entrance. On occasion people use the quasi- } \\
\text { linear basin-shaped surface that forms a natural sediment trap inside } \\
\text { the lip of the cave-mouth rampart. These slopes and hollows are also } \\
\text { locations for fires and food preparation, consumption, and discard. The } \\
\text { stream edge and stream basin location are often notably dry, and only } \\
\text { very occasionally affected by colluvial processes on the cave rampart } \\
\text { slope. In their lower parts they are affected by infrequent small-scale } \\
\text { fluvial erosion and subsequent deposition by streams and ponds. Small- } \\
\text { scale bioturbation by small animals of the stream-pool deposits; episodic } \\
\text { bioturbation from more stable surfaces on the cave rampart by larger } \\
\text { animals. Possible influx of loess from China. Guano pile continues to } \\
\text { accumulate within the cave as Unit G. }\end{array}$ \\
\hline $\begin{array}{l}\text { Ca. } 50,000 \text { в.P. }- \\
\text { ca. } 45,000 \text { в.P. }\end{array}$ & $\begin{array}{l}\text { Collapse of cave-mouth stalagmite columns; the cave-mouth rampart leads } \\
\text { to accumulation of Unit } 2 \mathrm{C} \text { as colluvium; and Unit } 2 \text { episodically in } \\
\text { stream and pools, which are sometimes interbedded with Unit } 2 \mathrm{C} \text {. The } \\
\text { west margin of Unit } 2 \text { is sometimes against limestone bedrock. Guano } \\
\text { accumulates (Unit G). }\end{array}$ \\
\hline Late Pleistocene & $\begin{array}{l}\text { Guano mound develops within the cave (Unit } G \text { ); earlier debris flows from } \\
\text { within the cave of Units } 1, C \text {, and } M \text {, whose stratigraphic relationships } \\
\text { are unclear. }\end{array}$ \\
\hline
\end{tabular}

${ }^{a}$ (Based on Barker et al. 2000, 2001, 2002a, 2002b, 2003, and this paper). All age estimates are based upon uncalibrated radiocarbon dates.

organically rich colluvium, and guano. In modern times, leaf peat and midden added to its form.

The cave entrance rampart formed and sheltered a small basin from the external world. This basin was also protected by the cave mouth overhang, and by the north wall and rock overhang inside the cave.

In the period from before ca. 45,000 B.P. to ca. 38,000 B.P., this basin infilled with fluvial and shallow pond sediments, interspersed with periods of channeling, nondeposition, and desiccation. Times of deposition are likely to indicate substantial storms or persistently wet seasons. Evidence of nondeposition and desiccation appears to indicate a climate that was drier than today. 
The fluvial and pond deposits were interbedded with colluvium and reworked palaeosols from the cave entrance rampart, reflecting the coincidence of slope colluviation with stream flow.

The archaeological remains in the West Mouth accumulated within this protected shallow basin. These sediments are radiocarbon dated before ca. 45,000 B.P. until ca. 38,000 B.P., with the sediments that included the Deep Skull dated to ca. $45,000-43,000$ B.P. The basin was a natural trap and the remains could have accumulated by a variety of processes including slope wash, stream flow, gravity, and animal and human activities within and on its margins.

Episodes of small-scale bioturbation, during and after deposition, complicate and augment the evidence of the geomorphological and archaeological processes.

The archaeology is preserved because a mudflow of guano plowed into the cave mouth deposits shortly before ca. 38,000 B.P., causing local sediment deformation and burial of the archaeological evidence. This mudflow may have occurred over a period of minutes or hours and its trigger has no evident relationship with fluctuations in the external environment.

The mudflow was subsequently affected by surface wash, but there is no direct evidence of human activity immediately adjacent to the cave entrance barrier after this event until the formation of Unit 4 at about 27,000 B.P.

A second major series of depositional events took place adjacent to the cave mouth rampart beneath the rock overhang (Fig. 1). This sequence occurred after the mudflow dated shortly before 38,000 B.P.

A shallow basin was formed by subsidence above a sinkhole adjacent to the cave wall and below the cave overhang.

A sequence of fine-grained sediments and archaeological deposits, including Harrisson's "habitation deposits," accumulated in this basin. These reflect human activity during the period from before ca. 19,500 B.P. to ca. 8500 в.P. (uncalibrated).

The lithological properties of Unit 4 suggest moister climatic conditions than in Units 2C and 2, though evidence is limited.

Over much of this time the guano deposits continued to accumulate and to be reworked, while the guano-based mudflows, the colluvium, and the much later midden in the cave lip entrance deposits were affected by the diagenetic growth of gypsum crystals.

In general, it is possible to correlate the principal components of the above sequence with some of those noted by earlier excavators (Table 1), though it is clearly far more complex in origin, stratigraphy, and detail than realized hitherto. While understanding that complexity is clearly essential for interpreting the human settlement and burial evidence found within the Niah sequence, the present findings may be of wider significance for studies of the prehistory of Sunda and Sahul.

\section{ACKNOWLEDGMENTS}

We thank the Chief Minister's Department of Sarawak for permission to undertake the fieldwork at Niah, and the staff of Sarawak Museum, especially its director, Sanib Said, and assistant director, Ipoi Datan, for their support and encouragement. Reconnaissance by DG during 1999 in the Niah Caves was funded by the British Academy's Committee for Southeast Asian Studies and the University of Adelaide 
through a visiting fellowship. The bibliography makes clear that this paper draws on the research of many scholars collaborating in the Niah Cave Project, whose work is published in the Sarawak Museum Journal. Their help and contributions are gratefully acknowledged, especially those of the project's coordinator, Graeme Barker, and the excavation director, Tim Reynolds.

\section{REFERENCES CITED}

Aharon, P., And J. Chappell

1986 Oxygen isotopes, sea level changes and temperature history of a coral reef environment in New Guinea over the last $10^{5}$ years. Palaeogeography, Palaeoclimatology, Palaeoecology $56: 337-379$.

ANDERSON, DOUglas D.

1997 Cave archaeology in Southeast Asia. Geoarchaeology 12(6):607-638.

Anshari, Gusti, A. Peter Kershaw, and Sander van der Kaars

2001 A Late Pleistocene and Holocene pollen and charcoal record from peat swamp forest, Lake Sentarum Wildlife Reserve, West Kalimantan, Indonesia. Palaeogeography, Palaeoclimatology, Palaeoecology $171: 213-228$.

Ashton, P. S.

1995 Biogeography and ecology, in Tree Flora of Sabah and Sarawak. Vol. 1: 43-51, ed. E. Soepadmo and E. Wong. Kuala Lumpur: Forestry Research Institute of Malaysia, Sabah Forest Department, and Sarawak Forest Department.

Baillie, I. C.

1978 Studies of Site-Forest Relationships in Mixed Dipterocarp Forest of Sarawak. Ph.D. diss. University of Aberdeen, Aberdeen.

Banda, Richard M., and F. Heward

2000 The General Geology of the Niah Caves Area, Sarawak. Unpublished report. Sarawak Minerals and Geosciences Malaysia Department, Kuching.

Barker, Graeme, Huw Barton, Paul Beavitt, Simon Chapman, Michael Derrick, Chris Doherty, Lucy Farr, David Gilbertson, Chris Hunt, Wayne Jarvis, John Krigbaum, Bernard Maloney, Sue Mclaren, Paul Pettitt, Brian Pyatt, Tim Reynolds, Garry Rushworth, and MARK STEPHENS

2000 The Niah Cave Project: Preliminary report on the first (2000) season. Sarawak Museum Journal 55 (n.s. 76) : 111-149.

Barker, Graeme, Dana Badang, Huw Barton, Paul Beavitt, Michael Bird, Patrick Daly, Chris Doherty, David Gilbertson, Ian Glover, Chris Hunt, Jessica Manser, Sue McLaren, Victor Paz, Brian Pyatt, Tim Reynolds, Jim Rose, Garry Rushworth, and Mark Stephens 2001 The Niah Cave Project: The second (2001) season of fieldwork. Sarawak Museum Journal 56 (n.s. 77) : 37-119.

Barker, Graeme, Huw Barton, Paul Beavitt, Michael Bird, Patrick Daly, Chris Doherty, David Gilbertson, Chris Hunt, John Krigbaum, Helen Lewis, Jessica Manser, Sue McLaren, Victor Paz, Phil Piper, Brian Pyatt, Ryan Rabett, Tim Reynolds, Mark Stephens, Jim Rose, Garry Rushworth, and Mark Stephens

$2002 a$ Prehistoric foragers and farmers in Southeast Asia: Renewed investigations at Niah Cave, Sarawak. Proceedings of the Prehistoric Society 68:147-164.

Barker, Graeme, Huw Barton, Michael Bird, Franca Cole, Patrick Daly, David Gilbertson, Chris Hunt, John Krigbaum, Cynthia Lampert, Helen Lewis, Lindsay Lloyd-Smith, Jessica Manser, Sue Mclaren, Francesco Menotti, Victor Paz, Phil Piper, Brian Pyatt, Ryan Rabett, Tim Reynolds, Mark Stephens, Gill Thompson, Mark Trickett, and Paula WHITTAKER

$2002 b$ The Niah Cave Project: The third (2002) season of fieldwork. Sarawak Museum Journal 57 (n.s. 78): 87-177.

Barker, Graeme, Huw Barton, Michael Bird, Franca Cole, Patrick Daly, Alan Dykes, Lucy Farr, David Gilbertson, Tom Higham, Chris Hunt, Stephanie Knight, Edmund Kurui, Helen Lewis, Lindsay Lloyd-Smith, Jessica Manser, Sue Mclaren, Francesco Menotti, Phil Piper, Brian Pyatt, Ryan Rabett, Tim Reynolds, Jonathon Shimmin, Gill Thompson, and MARK TRICKETT 
2003 The Niah Cave Project: The fourth (2003) season of fieldwork. Sarawak Museum Journal 57 (n.s. 78): 45-120.

Bellwood, Peter

1997 Prehistory of the Indo-Malaysian Archipelago, 2nd ed. Honolulu: University of Hawai'i Press.

Bird, Michael, L. K. Ayliffe, K. Fifield, R. Cresswell, and Chris Turney

1999 Radiocarbon dating of "old" charcoal using a wet oxidation-stepped combustion procedure. Radiocarbon 41:127-140.

Bird, Michael, Geoffrey Hope, and David Taylor

2004 Populating PEP II: The dispersal of humans and agriculture through Austral-Asia and Oceania. Quaternary International 118-119:145-163.

BRANDON-JONES, D.

1998 Pre-Glacial Bornean primate impoverishment and Wallace's Line, in Biogeography and Geological Evolution of SE Asia: 393-404, ed. J. D. Holloway and R. Hall. Leiden: Backhuys.

Brothwell, Don R.

1960 Upper Pleistocene human skull from Niah caves, Sarawak. Sarawak Museum Journal 9 (n.s. 15-16):323-349.

Burns, S. J., D. Fleitmann, A. Matter, J. Kramers, and A. A. Al-Subbary

2003 Indian Ocean climate and an absolute chronology over Dansgaard/Oeschger events 9 to 13. Science $301: 1365-1367$.

Colcutt, Simon

1979 The analysis of Quaternary cave sediments. World Archaeology 10(3):290-301.

CRANBROOK, EARL OF

2000 North Borneo environments of the past 40,000 years: Archaeozoological evidence. Sarawak Museum Journal 55 (n.s. 76): 61-109.

Cranbrook, Earl of, and D. S. Edwards

1994 Belalong-A Tropical Rain Forest. Singapore: Royal Geographical Society and Sun Tree Publishing.

Dunn, F. L., AND D. F. Dunn

1977 Maritime adaptations and the exploitation of marine resources in Sundaic Southeast Asian prehistory. Modern Quaternary Research in Southeast Asia 3:1-28.

Dykes, Alan

2003 Investigating the geotechnical properties of guano. In Barker et al., The Niah Cave Project: The fourth (2003) season of fieldwork. Sarawak Museum Journal 57 (n.s. 78): 45120 .

Esposito, Massimo, Jean-Louis Reyss, Yaowalak Chaimanee, and Jean-Jaques Jaeger

2002 U-series dating of fossil teeth and carbonates from Snake Cave, Thailand. Journal of Archaeological Science 29:341-349.

Everett, Alfred H., John Evans, And George Busk

1879- Report on the exploration of the caves of Borneo; and introductory remarks; and note 1880 on the bones collected. Proceedings of the Royal Society of London 30:310-319.

Farrant, Andrew, Peter Smart, Fiona Whitaker, and Don Tarling

1995 Long-term Quaternary uplift rates inferred from limestone caves in Sarawak, Malaysia. Geology $23: 357-360$.

Gathorne-Hardy, F. J., Syaukani, R. G. Davies, P. Eggleton, and D. T. Jones

2002 Quaternary rainforest refugia in southeast Asia: using termites (Isoptera) as indicators. Biological Journal of the Linnean Society 75:453-466.

Gilbertson, David D.

2000 Report on Grant in Support of Research: Sarawak-The Great Cave of Niah. Unpublished report. British Academy's Committee for Southeast Asian Studies, London.

Gillieson, David

1996 Caves: Processes, Development, and Management. Oxford: Blackwell Publishers.

Gingele, Franz. X., Patrick De Dekker, Aurélie Girault, and François Guichard

2002 History of the South Java Current over the past 80 ka. Palaeogeography, Palaeoclimatology, Palaeoecology 183 : 247-260. 
Glover, Ian C.

1979 The effects of sink action on archaeological deposits in caves: An Indonesian example. World Archaeology 10(3): 302-317.

GunN, JoHn, ED.

2003 Encyclopedia of Caves and Karst Science. New York and London: Routledge.

HARrison, TERry

1996 The palaeoecological context at Niah Cave, Sarawak: Evidence from the primate fauna. Bulletin of the Indo-Pacific Prehistory Association 14:90-100.

HARrisson, TOM

1958 The caves of Niah: A history of prehistory. Sarawak Museum Journal 8 (n.s. 12):549-595.

1959a Radiocarbon datings from Niah: A note. Sarawak Museum Journal 9 (n.s. 13-14):136142 .

$1959 b$ New archaeological and ethnological results from the Niah caves. Man 5:108.

1961a BH Soil Stratigraphy-Hell. Pink + White Deposit, depth note for Hell + adjacent areas. Unpublished site notebook in the Harrisson Archive. Sarawak Museum, Kuching.

$1961 b$ Niah excavations: Progress to 1961. Sarawak Gazette 1235:3-4.

1961c Niah excavations: Progress in 1961. Sarawak Gazette 1240:98-100.

196550,000 years of Stone Age culture in Borneo. Smithsonian Institution Annual Report 964:521-530.

1970 The Prehistory of Borneo. Asian Perspectives 13:17-45.

Hazebroek, Hans P., and Abang Kashim bin Adang Morshidi

2001 National Parks of Sarawak. Kota Kinabalu, Sabah: Natural History Publications.

Hunt, Chris, and Michael Bird

2002 The sedimentary sequence in the West Mouth: The interior guano mound. Pp. 93-95 in Barker et al., The Niah Cave Project: The third (2002) season of fieldwork. Sarawak Museum Journal 57 (n.s. 78) : 87-177.

Hunt, Chris, AND Alan Dykes

2003 The geomorphology of the Great Cave. Pp. 51-53 in Barker et al., The Niah Cave Project: The fourth (2003) season of fieldwork. Sarawak Museum Journal 57 (n.s. 78): 45-119.

Hunt, Chris, and Garry Rushworth

In press Pollen taphonomy of airfall sediments in the West Mouth of the Great Cave of Niah, Sarawak. Journal of Archaeological Science.

Jelinek, A. J., W. R. Farrand, G. Haas, A. Horowitz, and P. Goldberg

1973 New excavations at Tabun Cave, Mount Carmel, Israel: A preliminary report. Palaeorient $1: 151-183$.

Kershaw, Peter A., Bruno David, Nigel Tapper, Dan Penny, and Jonathon Brown, eds.

2002 Bridging Wallace's Line: The Environmental and Cultural Dynamics of the SE-Asian-Australian Region. Advances in Geoecology 34. Reiskirchen: Catena Verlag.

Kershaw, Peter A., Dan Penny, Sander van der Kaars, Dusti Anshari, and Asha THAMOTHERAMPILLAI

2001 Vegetation and climate in lowland southeast Asia at the Last Glacial Maximum, in Faunal and Floral Migrations and Evolution in SE Asia-Australasia: 227-236, ed. I. Metcalfe, J.M.B. Smith, M. Morwood, and I. Davidson. Lisse: A. A. Balkema.

KRIGBAUM, JOHN

2000 Human Paleodiet in Tropical Southeast Asia: Isotopic Evidence from Niah Cave and Gua Cha. Ph.D. diss. New York University, New York.

2003 Neolithic subsistence patterns in northern Borneo reconstructed with stable isotopes of enamel. Journal of Anthropological Archaeology 22:292-304.

LAmbeck, Kurt, and John Chappell

2001 Sea level change through the last glacial cycle. Science 292:679-686.

LAVERTy, MARTiN

1983 Borneo 1983: Some karst in the Poenrisen area of Sarawak. Oxford University Cave Club Proceedings 11.

Martinez, J. Ignacio, Patrick De Dekker, and Timothy Burrows

2002 Palaeoceanography of the Western Pacific Warm Pool during the Last Glacial Maximum: Long-term climatic monitoring of the maritime continent, in Bridging Wallace's Line: The 
Environmental and Cultural Dynamics of the SE-Asian-Australian Region: 147-172, ed. P. Kershaw, B. David, N. Tapper, D. Penny, and J. Brown. Advances in Geoecology 34. Reiskirchen: Catena Verlag.

Metcalf, Ian

2002 Tectonic history of the SE Asian-Australian region, in Bridging Wallace's Line: The Environmental and Cultural Dynamics of the SE-Asian-Australian Region: 29-48, ed. P. Kershaw, B. David, N. Tapper, D. Penny, and J. Brown. Advances in Geoecology 34. Reiskirchen: Catena Verlag.

MiLne, John

1966 Earthquakes and related phenomena in North and West Borneo. Sarawak Museum Journal 14 (n.s. 28): $1-5$.

Molengraaff, G.A.F.

1921 Modern deep-sea research in the east Indian archipelago. Geographical Journal 57:95121.

Ota, Y., J. Chappell, R. Kelley, N. Yonekura, E. Matsumoto, T. Nishmura, and J. Head

1993 Holocene coral reef terraces and coseismic uplift of the Huon Peninsula, Papua New Guinea. Quaternary Research 40:177-188.

PotTer, Lesley

2002 Forests and grassland, drought and fire: The island of Borneo in the historical environmental record (post-1800), in Bridging Wallace's Line: The Environmental and Cultural Dynamics of the SE-Asian-Australian Region: 339-356, ed. P. Kershaw, B. David, N. Tapper, D. Penny, and J. Brown. Advances in Geoecology 34. Reiskirchen: Catena Verlag.

PyatT, Brian F.

2003 Potential effects on human health of an ammonia-rich atmospheric environment in an archaeologically important cave in southeast Asia. Occupational and Environmental Medicine-BMJ On-line 60(12): 986.

RABETT, RYAN

2002 Bone Technology and Subsistence Variability in Prehistoric Southeast Asia. Ph.D. diss. University of Cambridge, Cambridge.

Sasowsky, Ira D., AND John Mylroie

2003 Studies of Cave Sediments: Physical and Chemical Records of Palaeoclimate. NATO Science Series. Dordrecht: Kluwer Academic Publishers.

Shackleton, Nicholas J., R. G. Fairbanks, T. C. Chiu, and F. Parrenin

2004 Absolute calibration of the Greenland time scale: Implications for Antarctic time scales and $\Delta^{14}$ C. Quaternary Science Reviews $23: 1513-1522$.

Sun, X. J., X. LI, And X. D. Chen

2000 The vegetation and climate at the last glaciation on the emerged continental shelf of the South China Sea. Palaeogeography, Palaeoclimatology, Palaeoecology 160(3-4):301-316.

TAPPER, NigeL

2002 Climate, climatic variability and atmospheric circulation patterns in the maritime continent region, in Bridging Wallace's Line: The Environmental and Cultural Dynamics of the SEAsian-Australian Region: 5-28, ed. P. Kershaw, B. David, N. Tapper, D. Penny, and J. Brown. Advances in Geoecology 34. Reiskirchen: Catena Verlag.

van der Kaars, Sander, Xuan Wang, Peter Kershaw, François Guichard, and Duddy Arifin SETIABUDi

2000 A late Quaternary palaeoecological record from the Banda Sea, Indonesia: Patterns of vegetation, climate and biomass burning in Indonesia and northern Australia. Palaeogeography, Palaeoclimatolog $\gamma$, Palaeoecology 155:135-153.

Voris, Harold K.

2000 Maps of Pleistocene sea levels in Southeast Asia: Shorelines, river systems and time durations. Journal of Biogeography 27 : 1153-1167.

Weiner, Steve, Paul Goldberg, and Ofer Bar-Yosef

2002 Three-dimensional distribution of minerals in the sediments of Hayonim Cave, Israel: Diagenetic processes and archaeological implications. Journal of Archaeological Science 29: 1289-1308. 
WhifFen, Trevor

2002 Plant biogeography of the Southeast Asian-Australian region, in Bridging Wallace's Line: The Environmental and Cultural Dynamics of the SE-Asian-Australian Region: 61-82, ed. P. Kershaw, B. David, N. Tapper, D. Penny, and J. Brown. Advances in Geoecology 34. Reiskirchen: Catena Verlag.

WiLFord, GEORge E.

1963 Limestone Cave Formation in Sarawak and North Borneo. Bulletin of the Geological Survey, Borneo Region 4. Kuching.

1964 The Geology of the Sabah and Sarawak Caves. Bulletin of the Geological Survey, Borneo Region 6. Sarawak.

WORLDBATH BATHYMETRY

2004 http://iriddl.columbia.edu/SOURCES/WORLDBATH/bath/ (at 3-6 ${ }^{\circ} \mathrm{N} ; 112-116^{\circ} \mathrm{E}$ ).

Yan, X.-H., C.-R. Ho, Q. Zheng, and V. Klemas

1992 Temperature and size variability of the western Pacific warm pool. Science 258: $1643-1645$.

Yokoyama, Y., K. Lambeck, P. De Dekker, P. Johnston, and L. K. Fifield

2001 Sea-level at the Last Glacial Maximum: Evidence from northwestern Australia to constrain ice volumes for oxygen isotope stage 2. Palaeogeography, Palaeoclimatology, Palaeoecology 165 : 281-297.

Zuraina Majid

1982 The West Mouth, Niah, in the prehistory of Southeast Asia. Sarawak Museum Journal 31 (n.s. 52), Special Monograph no. 3.

\section{ABSTRACT}

This paper presents initial interpretations of the processes and events responsible for the late Quaternary sequence in the West Mouth of the Great Cave of Niah, in the hot and humid lowland rainforest and swamp forest of Sarawak in Malaysian Borneo. It evaluates the geomorphological context of the site within the known pattern of rapid late Quaternary climate change. Attention is given to the proximity to the sea and the likelihood of humid tropical or cooler drier conditions. The stratigraphic succession is described and four units or lithofacies (2C, 2, 3 and 4) are recognized as being of particular geomorphological and archaeological importance. The key processes operating within the site are the accumulation and subsequent failure and flow of bat and bird guano, hillslope colluviation, and ephemeral stream flow and pond development. Units $2 \mathrm{C}$ and 2 contain the critical archaeology, including the Deep Skull from an anatomically modern human, discovered by Tom Harrisson. These were formed by colluviation from a complex cave-mouth rampart and stream flow from within the cave. The stream transported fine-grained sediment to a shallow pond, and both the stream and pond deposits show evidence for prolonged desiccation. Human activity is associated with these surfaces. The human remains and related archaeology are preserved because a mudflow (Unit 3) plowed into and overrode the land surface upon which the humans had lived, resulting in the deformation and burial of the surface and the preservation of the archaeological material. Provisional radiocarbon dates indicate that Units $2 \mathrm{C}$ and 2 accumulated from before ca. 45,000 B.P. until ca. 38,000 B.P. Dates bracketing the Deep Skull give this an age of ca. 45,000 B.P. to ca. 43,000 B.P. Overlying the mudflow, Unit 4 , a silty diamicton with a relatively high carbonate and organic content, appears to have formed by a mix of natural colluvial and human transport processes, and is associated with human cultural material. Unpublished radiocarbon dates indicate that this deposit formed from before ca. 19,500 B.P. to ca. 8500 B.P. (uncalibrated).

This interpretation of the site and its finds has required detailed reconstruction of the changing palaeogeography within and beyond the cave entrance and the nature and rate of geomorphological processes operating within the region, which have been placed within models for rapid Quaternary environmental change. The results suggest that during the earlier period of human presence in the Great Cave of Niah 
(earlier than ca. 45,000 B.P. until ca. 38,000 B.P.), the climate was episodically wet with much longer periods of relative dryness. During the later period of human occupancy (ca. 19,500 B.P. to ca. 8500 B.P. [uncalibrated]), the evidence is less secure and a slightly moister climate is suggested. KEYwORDs: ancient humans, bioturbation, Borneo, cave, climatic change, coastal change, geoarchaeology, geomorphology, guano, Niah, rainforest, Sarawak, site formation processes, Sunda, tropics. 